\title{
Fishing in life and death: Pleistocene fish-hooks from a burial context on Alor Island, Indonesia
}

Sue O'Connor ${ }^{1, *}$, Mahirta ${ }^{2}$, Sofía C. Samper Carro ${ }^{1,3}$, Stuart Hawkins ${ }^{1}$, Shimona Kealy ${ }^{1}$, Julien Louys ${ }^{1} \&$ Rachel Wood $^{4}$

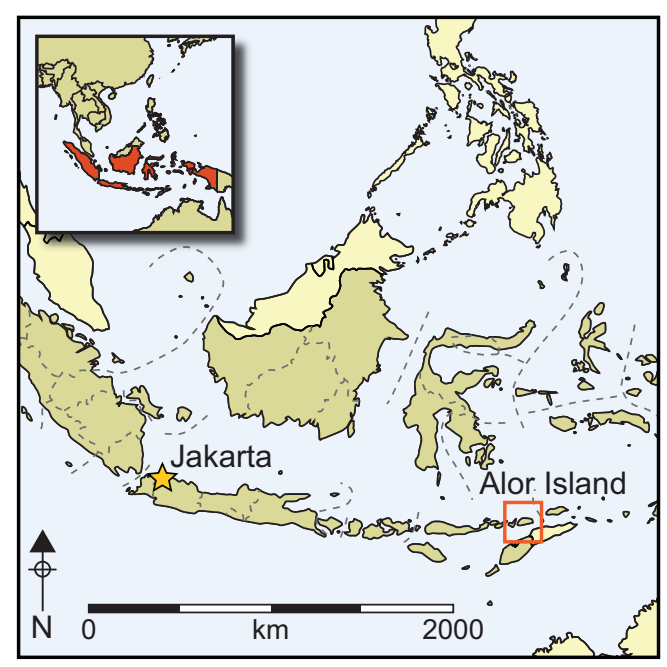

Fish-hooks discovered among grave goods associated with an adult female burial at the Tron Bon Lei rockshelter on the island of Alor in Indonesia are the first of their kind from a Pleistocene mortuary context in Southeast Asia. Many of the hooks are of a circular rotating design. Parallels found in various other prehistoric contexts around the globe indicate widespread cultural convergence. The association of the fish-hooks with a human burial, combined with the lack of alternative protein sources on the island, suggest that fishing was an important part of the cosmology of this community. The Tron Bon Lei burial represents the earliest-known example of a culture for whom fishing was clearly an important activity among both the living and the dead.

Keywords: Southeast Asia, Indonesia, Pleistocene, fishing, burial, cosmology

\section{Introduction}

The treatment of fishing in the afterlife amongst Pleistocene maritime cultures has received little attention in the archaeological literature. This is probably because burials of this age are rare in coastal contexts, with most Pleistocene coastal sites having been submerged by sea-level rise following the end of the Last Glacial phase. Here, we report on an

1 Archaeology and Natural History, School of Culture, History and Language, College of Asia and the Pacific, Australian National University, Canberra 2601, Australia

2 Jurusan Arkeologi, Fakultas Ilmu Budaya, Universitas Gadjah Mada, Yogjakarta, Indonesia

3 School of Archaeology and Anthropology, College of Arts and Social Sciences, Australian National University, Canberra 2601, Australia

4 Earth Chemistry, Research School of Earth Sciences, Australian National University, Canberra 2601, Australia

* Author for correspondence (Email: sue.oconnor@anu.edu.au)

(C) Antiquity Publications Ltd, 2017. This is an Open Access article, distributed under the terms of the Creative Commons Attribution licence (http://creativecommons.org/licenses/by/4.0/), which permits unrestricted reuse, distribution, and reproduction in any medium, provided the original work is properly cited. 
assemblage of shell fish-hooks recovered from a burial in Tron Bon Lei rockshelter on Alor Island, Indonesia, dated to the Terminal Pleistocene. These are the oldest-known fish-hooks associated with mortuary practices from anywhere in the world, and perhaps indicate that fishing equipment was viewed as essential for the transition to the afterlife in the Wallacean Islands, where terrestrial fauna is depauperate, and where fish and other marine resources were the mainstay of the diet.

The majority of early prehistoric fish-hooks from around the world derive from habitation contexts. The oldest example comes from Japan, where a single-piece, rotating hook was recently found on Okinawa Island in a stratigraphic layer bracketed by AMS dates of c. $23000 \mathrm{cal} \mathrm{BP}$ and $20000 \mathrm{cal} \mathrm{BP}$ (Fujita et al. 2016). Single-piece, shell fish-hooks have been found in Timor-Leste, where one from Lene Hara Cave has been directly AMS dated to $c .11000 \mathrm{cal}$ BP (O'Connor et al. 2011). Another shell hook from Jerimalai Shelter in Timor-Leste is of a comparable age to the Okinawa find, in a deposit context dated to between c. 23000 and $16000 \mathrm{cal} \mathrm{BP}$ (O'Connor et al. 2011). Single-piece hooks of bone and ivory appear in Europe in the Final Palaeolithic about 12000 years ago, becoming more common in the Mesolithic (Gramsch et al. 2013). On Cedros Island, Mexico, hooks appear approximately 11000 years ago (Des Lauriers 2010), and are present in coastal Chile by about $8000 \mathrm{cal}$ BP (Llagostera 1992). In coastal California, shell hooks were not used until the Late Holocene, but bone gorges appear by $c .10000 \mathrm{cal}$ BP (Rick et al. 2002).

Prior to the finds described here, the earliest hooks with a mortuary association were the composite slate shaft pieces from the Ershi cemetery in Siberia, in a riverine environment and dated to the late Mesolithic $c .9000 \mathrm{cal} \mathrm{BP}$ (Basaliiski 2010). In a maritime context, the earliest burials with fish-hooks are from Oman, where rotating hooks made of pearl shell (Pinctada radiata) have been dated to $c .6000 \mathrm{cal} \mathrm{BP}$ from their depositional context (Santini 1987).

A preliminary archaeological investigation conducted in June 2014 at Tron Bon Lei shelter (pit B), on the south coast of Alor (Figure 1), uncovered a partial human skeleton in a layer dating to the Terminal Pleistocene, containing five shell fish-hooks and a perforated bivalve (Figure 2). Direct dating of one of the hooks and radiocarbon dates on charcoal associated with the burial demonstrates that the body and grave goods were buried shortly after $c .12000$ years cal BP (Table 1). Here we describe the shell fish-hooks, the context of the burial and the profoundly significant behavioural patterns that they represent within the context of Asia-Pacific prehistory and global technological adaptations more widely.

\section{Archaeological context}

Alor is part of the Lesser Sunda chain of islands in eastern Indonesia. Largely volcanic in origin, Alor has a mountainous interior, dropping steeply to a narrow coastal margin. The island has a land area of about $2100 \mathrm{~km}^{2}$. As one of the islands of Wallacea, Alor has never been connected by a landbridge to Sunda (the enlarged southernmost extension of Eurasia), Sahul (Australia, New Guinea and the Aru Islands), or to the larger islands of Timor or Flores. During the lower sea stand of the Last Glacial Maximum about 21000 years ago, when sea levels were about $130 \mathrm{~m}$ below those of the present, it merged with neighbouring Pantar, Pura, Kambing, Rusa, Ternate and Treweng Islands, forming a (C) Antiquity Publications Ltd, 2017 


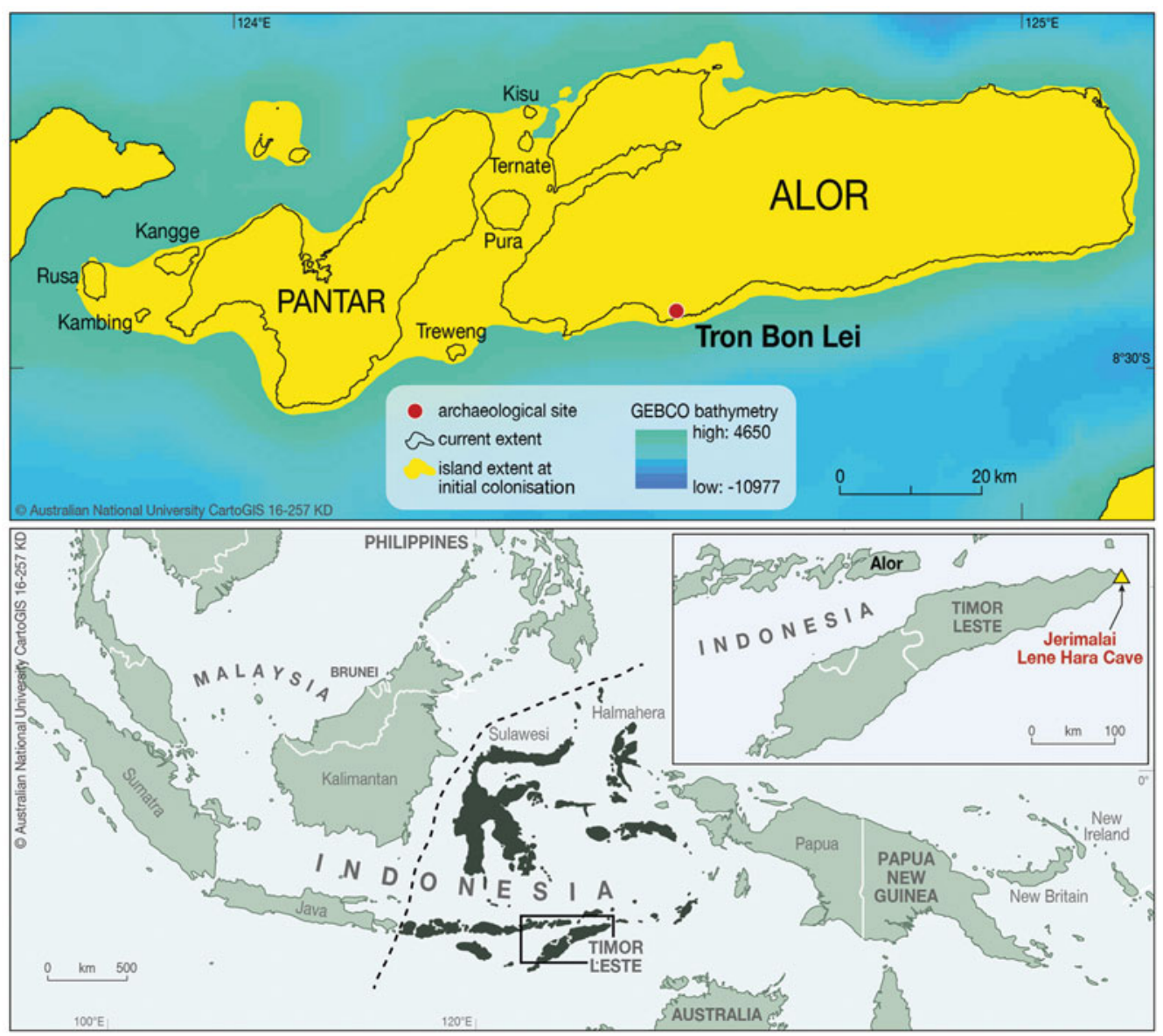

Figure 1. Map (upper) showing the location of Tron Bon Lei, the current extent of Alor, Pantar and other neighbouring islands, and the island as it would have been at $22000 \mathrm{cal}$ BP. The lower map shows Wallace's Line (black dashed line) and the location of the Wallacean Islands in black; the inset shows Timor-Leste and the location of Jerimalai and Lene Hara Cave.

'mega island' of about $3800 \mathrm{~km}^{2}$ (based on an average uplift rate of approximately $0.5 \mathrm{~m} / \mathrm{ka}$ ) (Figure 1, upper map). It is at about this time that the first evidence for occupation in Tron Bon Lei occurs. The Tron Bon Lei pit B shelter is one of several rockshelters sharing its name with a volcanic ridge above the village of Lerabain (Figure 3A-B). The pit B shelter is about $33 \mathrm{~m}$ above sea level and $160 \mathrm{~m}$ inland from the current seashore (Figure $4 \mathrm{~A}-\mathrm{B}$ ).

An exploratory $1 \mathrm{~m}^{2}$ test pit (pit B) was placed inside of the dripline and excavated to an average depth of $3.2 \mathrm{~m}$, where bedrock was encountered (Figures $3 \mathrm{~B} \& 4 \mathrm{~B}$ ). Excavation employed arbitrary $50 \mathrm{~mm}$ excavation units within stratigraphic layers. Thirteen stratigraphic layers were identified and have been described elsewhere (Figure 5) (Samper Carro et al. 2016). Radiocarbon dating suggests three main phases of activity at the site (Table 1): 1) Late Holocene (c. 4000-3000 cal BP); 2) Terminal Pleistocene to Early Holocene (c. 12000-7500 cal BP); 3) late Pleistocene (c. 21000-18000 cal BP). While there appears to be a chronological hiatus between each of these occupation phases, there is 


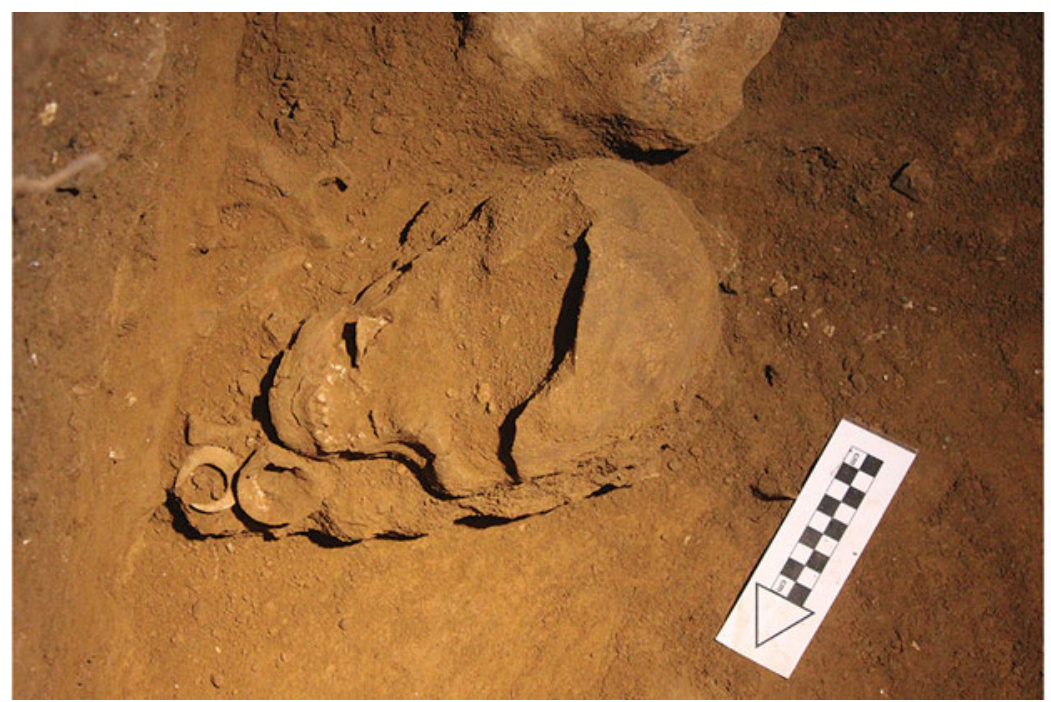

Figure 2. Tron Bon Lei cranium, photographed during excavation. Fish-hook $A$ and perforated bivalve to the north of the mandible. (Photograph by Sofia Samper Carro.)

neither evidence of sterile deposits separating them, nor of sedimentary unconformities or lag deposits indicative of their erosion or removal.

\section{The Tron Bon Lei assemblage}

The upper excavation units dating to the Late Holocene contained a small number of earthenware sherds. Shellfish, faunal remains and stone artefacts manufactured from basalt, obsidian and chert were found throughout the sequence, but were less abundant in the pottery-bearing layers. The faunal assemblage consists almost entirely of marine resources including fish, marine molluscs, urchins and crustacea and a small quantity of marine turtle bone. Pit B produced 28745 fish bones (number of identified specimens (NISP)), which accounted for 96.84 per cent of identified bone (Samper Carro et al. 2016). The nonfish bone comprises marine turtle (Cheloniidae), fruit bat (Pteropodidae), squamate lizard (Lacertilia), murid (Muridae), shrew (Soricidae), snake (Serpentes) and bird (Aves), with a total NISP of 939, but at 3.16 per cent of the assemblage, their contribution to subsistence was minimal, and many of the small murids, shrews and reptiles may actually be derived from the activities of roosting barn owls (Hawkins et al. 2017).

Analysis of the fish bones has shown that carnivorous fish taxa dominate in the layers containing the burial, and that an increase in smaller herbivorous/omnivorous reef fish occurred during the Mid Holocene as the sea level rose and the coral reef was established (Samper Carro et al. 2016; see too the online supplementary material (OSM)).

\section{The Tron Bon Lei burial and grave goods}

The burial is in the south-east area of pit B (Figures 5-6). The frontal part of the skull began to emerge in excavation unit 39 (around a depth of $2.1 \mathrm{~m}$ ) and continued into excavation

(C) Antiquity Publications Ltd, 2017 

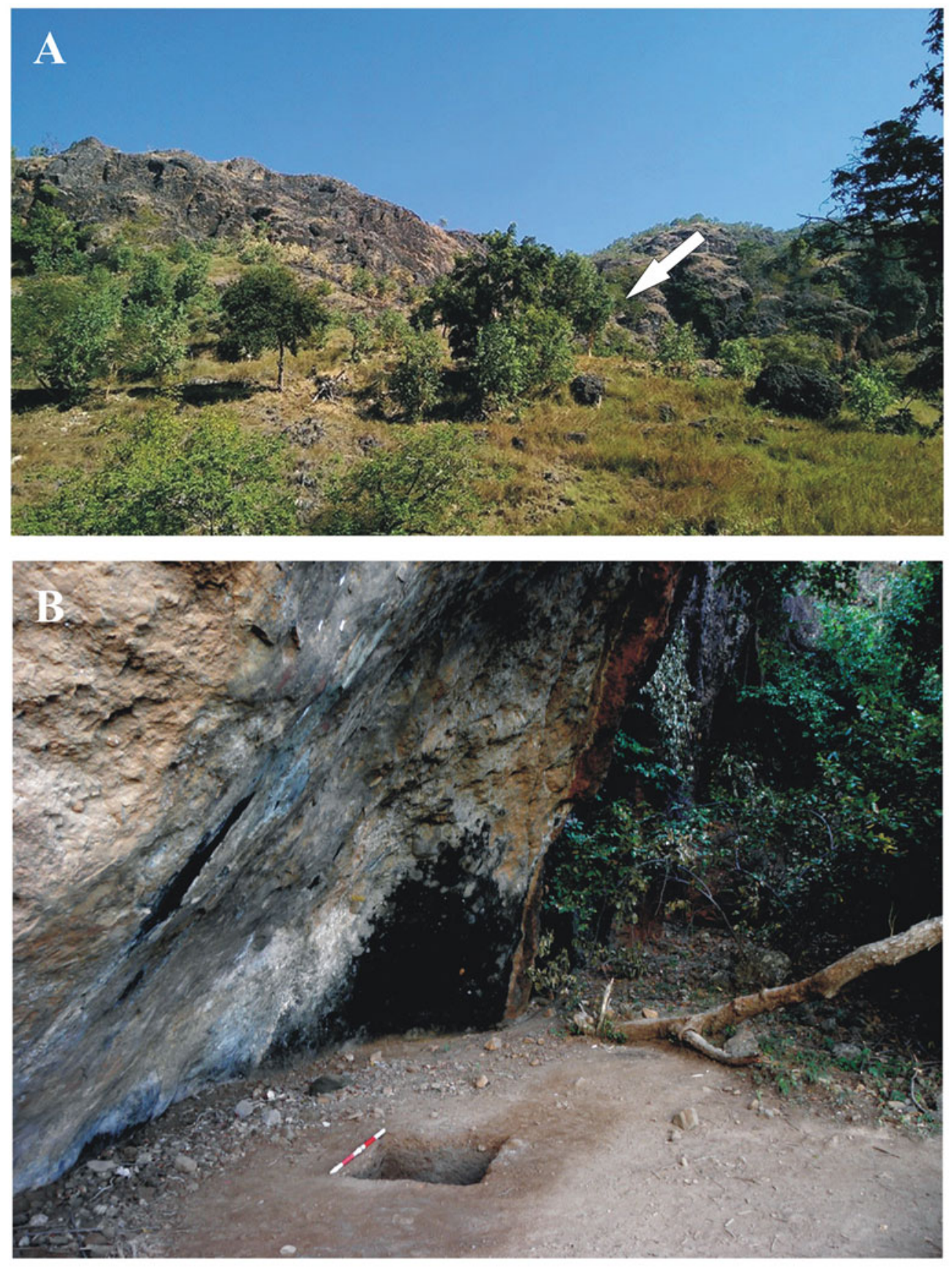

Figure 3. A) Northern view of the volcanic ridge where Tron Bon Lei is located. The white arrow indicates the general location of the rockshelters (photograph by permission of Putu Yuda); B) pit B looking east from the southern edge of the rockshelter (image from Samper Carro et al. 2016, reproduced with permission from Elsevier). 
Table 1. AMS radiocarbon dates from Tron Bon Lei pit B, Alor. Dates calibrated using OxCal v.4.2.4 against IntCal13 and Marine13 (Bronk Ramsey 2009; Reimer et al. 2013).

\begin{tabular}{|c|c|c|c|c|c|c|}
\hline Sample name & Sample type & $\begin{array}{l}\text { Quality } \\
\text { indicator* }\end{array}$ & $\delta^{13} \mathrm{C}^{\dagger 2}$ & $\begin{array}{l}\text { SANU- } \\
\text { number }\end{array}$ & $\begin{array}{l}\text { Radiocarbon } \\
\text { age (BP) }\end{array}$ & $\begin{array}{l}\text { Calibrated age } \\
\text { (cal BP, } 95.4 \% \\
\text { probability range) }\end{array}$ \\
\hline TB-B1-1 & $\begin{array}{c}\text { shell; Turbo sp. } \\
\text { Operculum }\end{array}$ & - & 1 & 42723 & $3275 \pm 20$ & $3195-3010$ \\
\hline TB-B1-3 & shell; Barbatia sp. & - & 4 & 42724 & $3395 \pm 20$ & $3345-3185$ \\
\hline TB-B1-4 & charcoal in situ & $54 \% \mathrm{C}$ & -27 & 41918 & $3065 \pm 20$ & $3350-3215$ \\
\hline TB-B1-5 & shell; oyster & - & 3 & 42725 & $5010 \pm 20$ & $5440-5295$ \\
\hline TB-B1-6 & charcoal in situ & $60 \% \mathrm{C}$ & -29 & 41919 & $3325 \pm 20$ & $3615-3475$ \\
\hline TB-B1-7 & charcoal in situ & $60 \% \mathrm{C}$ & -28 & 41920 & $3210 \pm 20$ & $3465-3380$ \\
\hline TB-B1-8 & charcoal in situ & $60 \% \mathrm{C}$ & -29 & 41921 & $3390 \pm 20$ & $3695-3575$ \\
\hline TB-B1-9 & charcoal in situ & $63 \% \mathrm{C}$ & -24 & 43924 & $3350 \pm 25$ & $3685-3490$ \\
\hline TB-B1-10 & charcoal in situ & $62 \% \mathrm{C}$ & -28 & 43925 & $3370 \pm 25$ & $3690-3560$ \\
\hline TB-B1-11 & charcoal in situ & $62 \% \mathrm{C}$ & -26 & 43926 & $3680 \pm 25$ & $4090-3925$ \\
\hline SW-6-L6 & charcoal in situ & $56 \% \mathrm{C}$ & -26 & 40123 & $6620 \pm 30$ & $7570-7440$ \\
\hline TB-B1-16 & charcoal in situ & $61 \% \mathrm{C}$ & -27 & 43927 & $6845 \pm 30$ & $7745-7610$ \\
\hline SW-5-L8 & charcoal in situ & $58 \% \mathrm{C}$ & -26 & 40121 & $7060 \pm 30$ & $7955-7835$ \\
\hline SW-4-L8 & charcoal in situ & $48 \% \mathrm{C}$ & -28 & 40120 & $7205 \pm 30$ & $8155-7955$ \\
\hline NW-3-L9 & charcoal in situ & $48 \% \mathrm{C}$ & -31 & 40039 & $7250 \pm 25$ & $8160-8005$ \\
\hline NW-2-L9 & charcoal in situ & $54 \% \mathrm{C}$ & -29 & 39539 & $7355 \pm 35$ & $8310-8035$ \\
\hline NW-1-L10 & charcoal in situ & $52 \% \mathrm{C}$ & -30 & 39538 & $8745 \pm 35$ & $9895-9560$ \\
\hline SW-2-L10 & charcoal in situ & $49 \% \mathrm{C}$ & -26 & 40118 & $8955 \pm 40$ & $10225-9915$ \\
\hline SW-R2-L11 & $\begin{array}{l}\text { shell; Haliotis } \\
\text { asinina }\end{array}$ & - & 2 & 40128 & $9340 \pm 35$ & $10245-10110$ \\
\hline B- 40 & $\begin{array}{l}\text { charcoal in eye } \\
\text { socket }\end{array}$ & $57 \% \mathrm{C}$ & -29 & 40125 & $10140 \pm 45$ & $12035-11500$ \\
\hline $\begin{array}{c}\text { TB-B1-41- } \\
\text { HOOK }\end{array}$ & $\begin{array}{l}\text { fish-hook; Trochus } \\
\text { niloticus }\end{array}$ & $\begin{array}{r}<0.3 \% \\
\text { calcite }\end{array}$ & -1 & 41825 & $10230 \pm 30$ & $11300-11130$ \\
\hline B-41 & $\begin{array}{l}\text { charcoal beneath } \\
\text { the skull }\end{array}$ & $67 \% \mathrm{C}$ & -27 & 40124 & $10445 \pm 50$ & $12545-12115$ \\
\hline SW-P-L12 & $\begin{array}{l}\text { shell; Haliotis } \\
\text { asinina }\end{array}$ & - & -1 & 40129 & $16210 \pm 60$ & $19235-18890$ \\
\hline B-58 & shell; Nerita sp. & - & 1 & 40130 & $17630 \pm 70$ & $21000-20560$ \\
\hline
\end{tabular}

Radiocarbon dates associated with the burial. Charcoal dates have been calibrated against IntCal13, and the shell date against Marine13 (Reimer et al. 2013) in OxCal v.4.2 (Ramsey 2009).

${ }^{*}$ Charcoal should contain more than approximately 50\%C. \%C was measured volumetrically during cryogenic collection and purification. If calcite was present in the aragonitic nacre from the shell hook, recrystallisation and thus contamination with groundwater carbonate may have occurred. \%calcite was determined by X-ray diffraction.

${ }^{\dagger} \delta^{13} \mathrm{C}$ was measured by AMS and used in date calculation. It is not comparable to $\delta^{13} \mathrm{C}$ values measured by isotope-ratio mass spectrometry.

unit 41 (reaching a depth of $2.26 \mathrm{~m}$ in the south-east corner) (Figures 2, $5 \& 6$ ). The frontal bone and facial area of the skull were found facing north and resting on the left zygomatic. The cranium, mandible and maxilla, some fragments of cervical vertebrae, rib fragments, pieces of both scapulae and the diaphysis of a left humerus were also recovered. The remainder of the burial extends into the east wall of the pit. The recovered bones were in anatomical association with one another, but as most of the skeleton remains unexcavated, (C) Antiquity Publications Ltd, 2017 


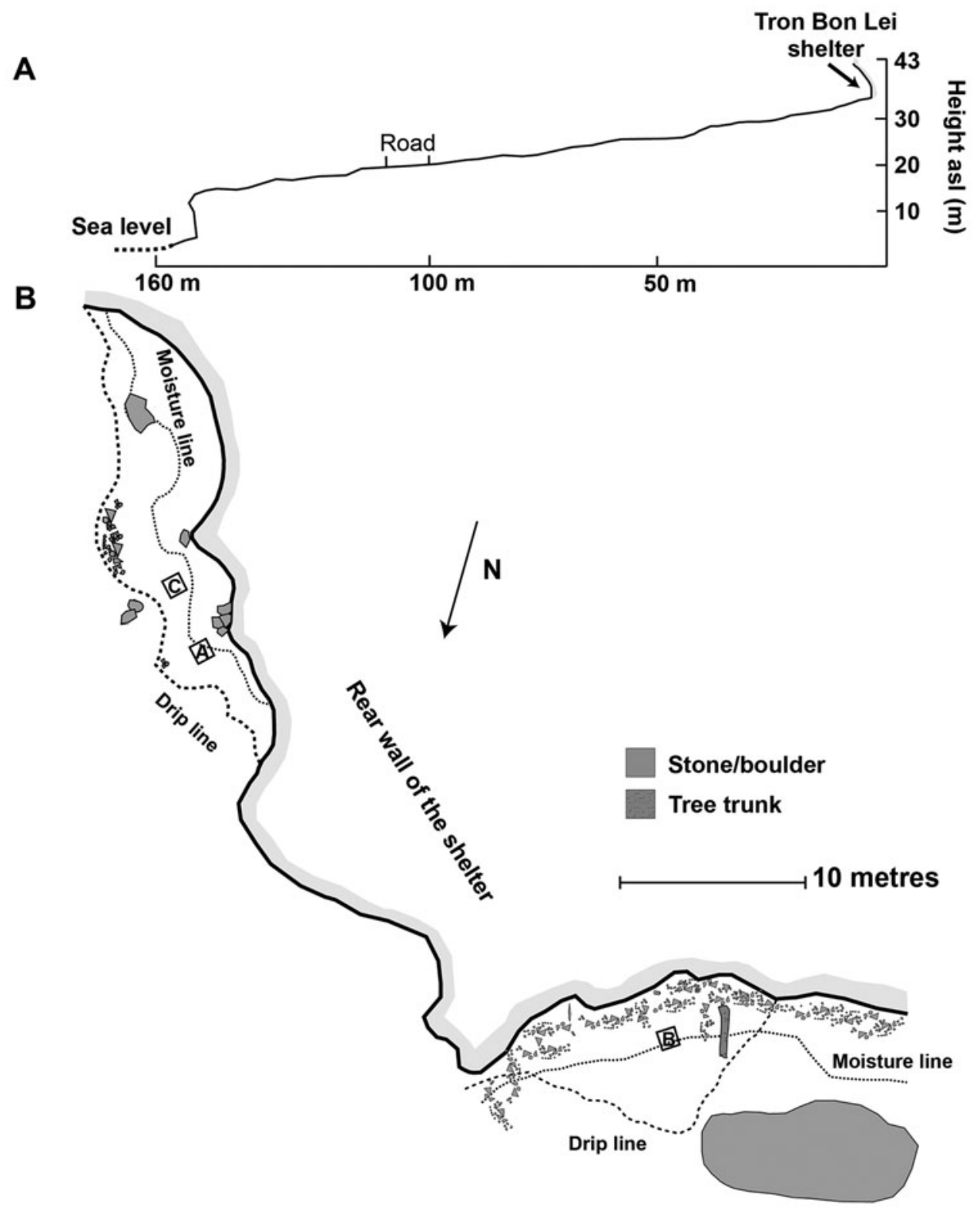

Figure 4. A) Transect showing the distance from sea level to Tron Bon Lei rockshelter; B) plan of Tron Bon Lei showing the location of test pit $B$ (and also test pits $A$ and $C$, not reported here); modified from Samper Carro et al. (2016), reproduced with permission from Elsevier.

it is not possible to tell if it is a primary or secondary burial. Our focus here is on the burial context rather than the skeletal analyses, which will be presented elsewhere.

As we do not have the full skeleton, it is not possible to sex the individual with confidence. Despite this, the presence of a relatively gracile skull possessing fully erupted 


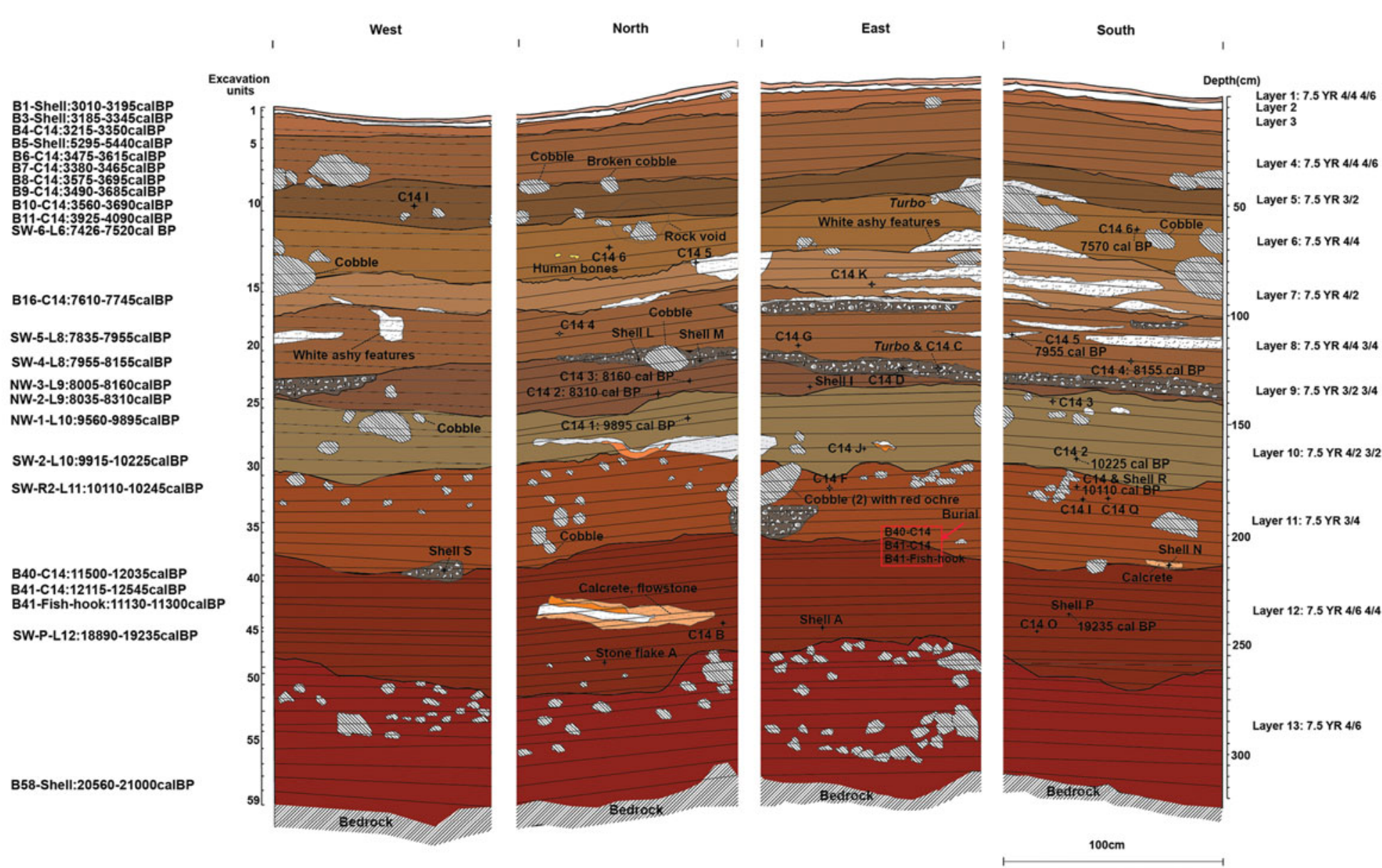

Figure 5. Stratigraphic drawing of the east section of the Tron Bon Lei pit B excavation, showing stratigraphic levels, excavation units, the location of samples taken for radiocarbon dates and the location of the burial and associated finds (red rectangle). 


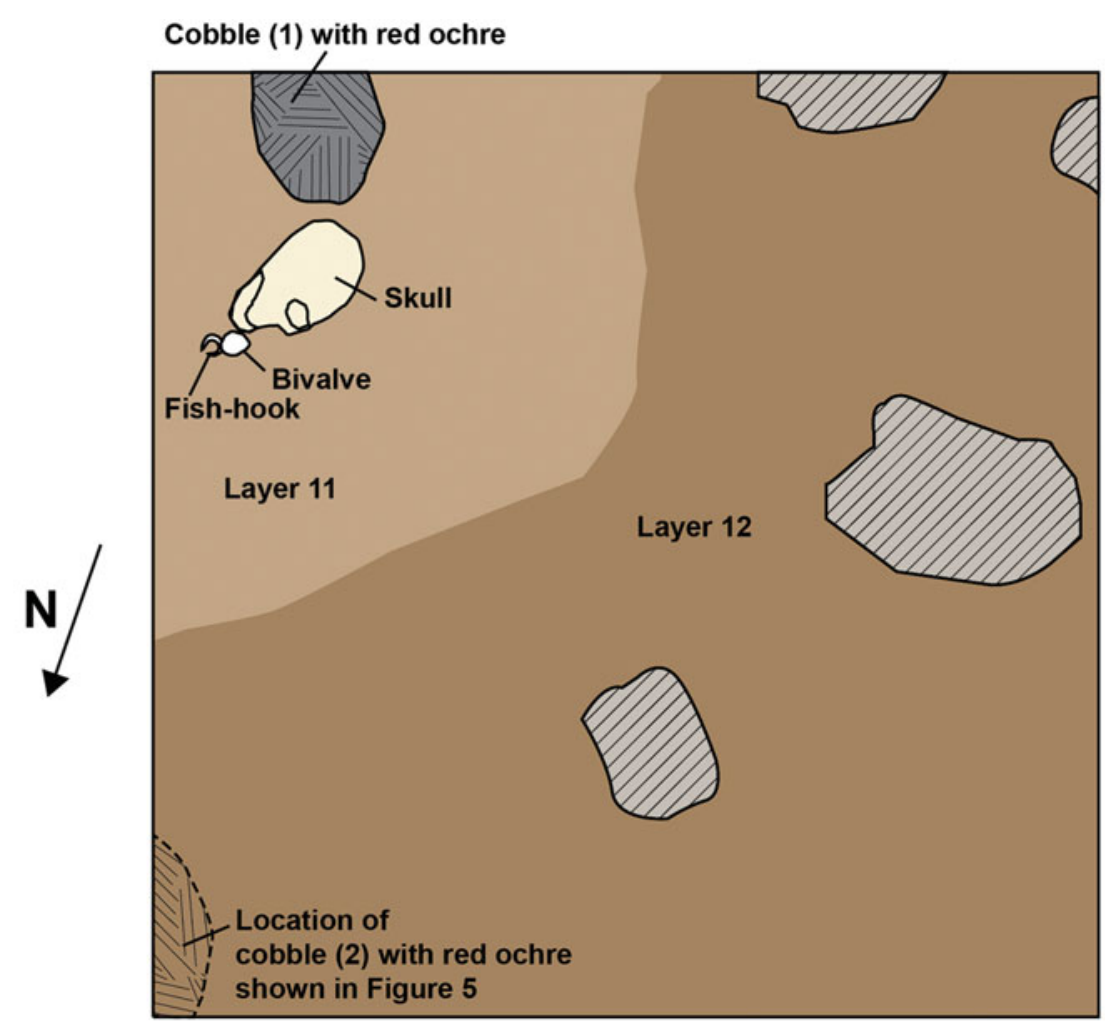

$50 \mathrm{~cm}$

Figure 6. Plan view of the Tron Bon Lei cranium showing the position of fish-hook A, bivalve and cobbles with red ochre. Cobble 2 is higher in the profile than cobble 1 and is not in the plan; its location is, however, shown in Figure 6. The burial is in the lighter sediment layer 11. The darker sediment in the northern and western part of the pit is layer 12.

third molars with moderate wear, a weakly developed superciliary ridge, lack of gonial eversion and reduced nuchal lines and mastoid processes are suggestive of an adult female. The direction of error makes it less probable that females will be misclassified, particularly in individuals that are not of advanced age such as this one (Meindl et al. 1985). As the excavation could not be extended in the 2014 season, and there was a danger that the site would be disturbed by local villagers after we left, the decision was made to remove the skeletal remains in pit B and leave the unexcavated bones in situ for future excavation.

\section{Stratigraphic context of the burial and grave goods}

Based on depth below the surface, the burial and grave goods are interred in layer 12; they were, however, confined in a pocket of sediment of the same colour and texture as layer 11 . It is thought that the burial was dug into the top of layer 12 from layer 11 . Thus the burial is thought actually to belong to layer 11 (Figures 5-6). The burial, and the cultural material associated with it were excavated separately from the darker sediments in plan at the same depth (layer 12), and designated as excavation units 39, 40 and 41 in burial context layer 11 to differentiate them from the excavation units with the same number in layer 12 . The body was interred fairly shallowly and associated with two flat cobbles that were coated in 
red ochre. One cobble was interred at the same level, and about $30 \mathrm{~mm}$ from the back of the skull (Figure 6, cobble 1), while the other was in the north-east corner of the pit, approximately 100-150mm higher than the top of the skull (Figures 5-6, cobble 2). The radiocarbon dates support the assignment of the burial to layer 11, confirming a shallow grave cut.

\section{AMS dating of the Tron Bon Lei burial context and grave goods}

A $\% \mathrm{~N}$ test (Brock et al. 2010, 2012) of bone from the skull indicated that insufficient collagen was preserved for radiocarbon dating. Instead, samples of charcoal found near the burial and one of the associated fish-hooks (hook C) were dated. Charcoal dates have been calibrated against IntCal13, and the shell date against Marine13 (Reimer et al. 2013) in OxCal v.4.2 (Bronk Ramsey 2009). A regional average $\Delta \mathrm{R}$ of $32 \pm 41{ }^{14} \mathrm{C}$ years was applied to the shell date (see OSM).

The upper part of the layer that the hooks were buried within (layer 11) has an AMS radiocarbon age of $c .10000 \mathrm{cal} \mathrm{BP}$ (S-ANU-40128: 9340土35 BP, 9935-10 $245 \mathrm{cal} \mathrm{BP}$ at 95.4\%) (Table 1). An AMS radiocarbon date of 11310-11 075 cal BP (S-ANU-41825: $10230 \pm 30 \mathrm{BP}$ ) on hook $\mathrm{C}$ is consistent with a date on a fragment of charcoal from within the left eye socket of the individual of 12 035-11 $500 \mathrm{cal}$ BP (S-ANU-40125: $10140 \pm 45$ $\mathrm{BP}$ ), when taking into consideration that the charcoal age may be affected by an old wood effect (see OSM). Charcoal from directly beneath the skull in excavation unit 41 was dated to $10445 \pm 50 \mathrm{BP}$ (S-ANU 40124), with a calibrated age of $12545-12115 \mathrm{cal} \mathrm{BP}(95.4 \%)$. The skeleton was therefore interred in the millennia after $12000 \mathrm{cal} \mathrm{BP}$.

\section{The Tron Bon Lei fish-hooks and bivalve}

An intact fish-hook (hook A) and a perforated bivalve were found directly beneath the chin (Figures $2 \& 6$ ). Three other fish-hooks were found around the mandible (hooks B, C and E) (Figure 7). A partial hook (D) was found under the mandible (Figure 8). All were within excavation unit 41 (Figure 5).

Single-piece fish-hooks are commonly divided into two main types: J-shaped hooks in which the point and shank are more or less parallel, and circular rotating hooks, in which the point curves inwards towards the shank, leaving only a narrow opening (gape) between the point end and the shank (Kirch 1985; Allen 1996). With the exception of the hook fragment (hook D; Figure 8), all of the fish-hooks (A, B, C and E) are rotating hooks (Figure 7 ). The hooks are described below and the measurements are provided in Table 2 (for the location of the measurements, see Figure 9).

The rotating hooks are made on Tectus niloticus shell and are almost circular with the shaft only slightly longer than the point, and with a narrow gape. All are thickest and widest at the bend, midway between the shank and the hook, to provide mechanical strength (see OSM). Hook E retains evidence of striae that are probably the result of attempts to remove the periostracum (outer layer) to expose the nacreous surface beneath (Figure 7), which may have helped attract fish (Fujita 2014: 129). Hook C was fragmented during excavation and a small fragment was used for AMS dating. Hook D is thinner and finer than the rotating hooks, and appears to be from a J-shaped hook that, if complete, would have had a straight shaft (Figure 8).

(C) Antiquity Publications Ltd, 2017 


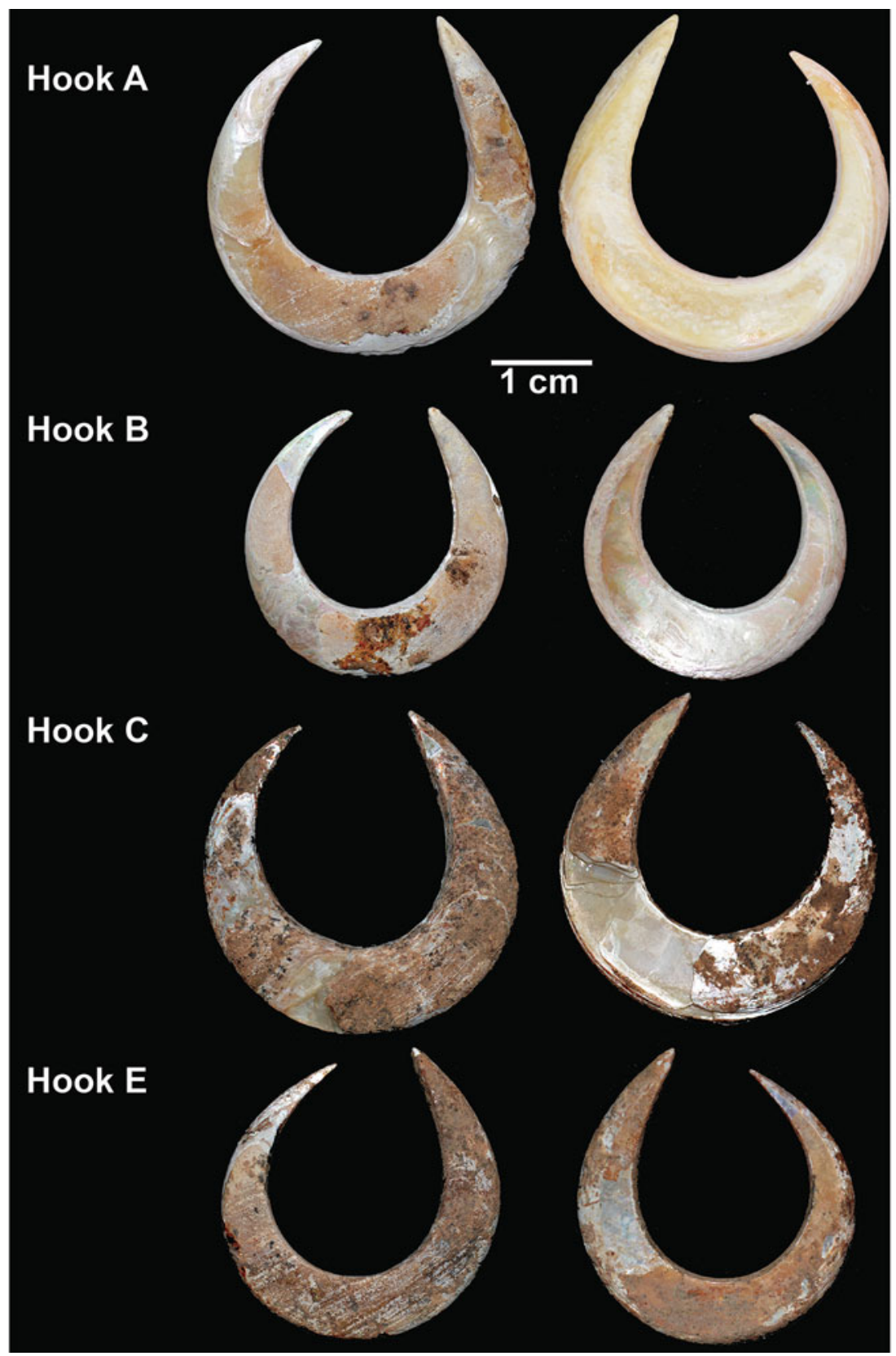

Figure 7. Circular rotating fish-hooks (A, B, C and E) found with the burial. (Photograph by Sofia Samper Carro.)

The bivalve, Vasticardium cf. flavum, was found next to hook A (Figure 2). It is a left valve and is perforated in the umbo region (Figure 10). Although cracked through the perforation, there is evidence of smoothing and polish, which may result from threading. There is also evidence of extreme wear and rounding on the ventral margin of the

(C) Antiquity Publications Ltd, 2017 


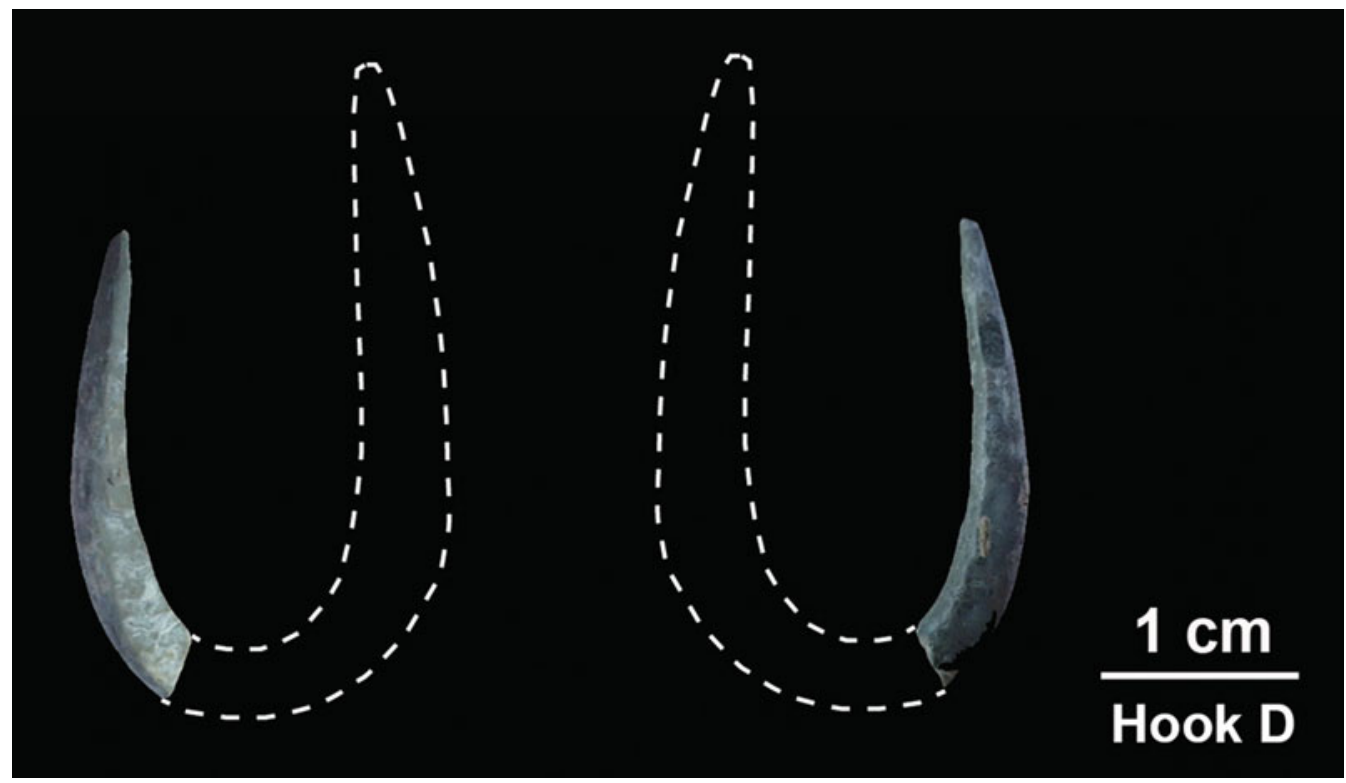

Figure 8. Tron Bon Lei fish-hook D. The dotted line shows the probable shape of the shaft.

valve consistent with use for scraping, and there are traces of a red colourant on the surface.

\section{Mechanical and functional attributes of fish-hooks with reference to the Tron Bon Lei assemblage}

Rotating hooks and J-shaped hooks have distinct mechanical properties and function very differently (Reinman 1967; Allen 1996). Nordhoff (1930: 156) describes the differences in the mechanical action and operation of the two types in Polynesia. With a J-shaped hook, the line must be pulled sharply when the fish bites to secure the catch, whereas with a rotating hook, the inward curved point and shank rotate in the prey's mouth when the bait is taken, and the fish essentially hooks itself as it swims away. The utility of rotating hooks vs J-shaped hooks will depend primarily on marine conditions and the desired prey. The rotating hook is regarded as the optimal choice in deep waters or where strong currents or wind prevent tension being maintained on the line (Reinman 1967; Johannes 1981; Allen 1996). Rotating hooks are also useful in shallow water when large fish are the target, and where coral heads can potentially snag a jabbing hook (Johannes 1981).

Some earlier writers suggested that the circular rotating hooks would not have been functional, as the gape (the distance between the hook point and the shaft) was so narrow (Bowers 1883). Near identical hooks have, however, been recorded ethnographically in Australia (Attenbrow 2010), Near and Remote Oceania (e.g. Anell 1955; Reinman 1967; Johannes 1981; Allen 1996) and California (Hoover 1973; Greenwood 1978). In Australia, such hooks were made and used exclusively by women. A wealth of ethnography records their primary function as being for fishing (Attenbrow 2010). Spare hooks were occasionally (C) Antiquity Publications Ltd, 2017 
Table 2. Measurements taken on fish-hooks.

\begin{tabular}{|c|c|c|c|c|c|c|c|c|}
\hline Artefact & $\begin{array}{l}\text { 1. Length of } \\
\text { hook at } \\
\text { shaft }(\mathrm{mm})\end{array}$ & $\begin{array}{l}\text { 2. Length of } \\
\text { hook at } \\
\text { point (mm) }\end{array}$ & $\begin{array}{l}\text { 3. Total } \\
\text { width of } \\
\text { hook }(\mathrm{mm})\end{array}$ & $\begin{array}{l}\text { 4. Width at } \\
\text { bend (mm) }\end{array}$ & $\begin{array}{l}\text { 5. Thickness } \\
\text { at bend of } \\
\text { hook }(\mathrm{mm})\end{array}$ & $\begin{array}{l}6 . \text { Thickness } \\
\text { at hook } \\
\text { point }(\mathrm{mm})\end{array}$ & $\begin{array}{l}\text { 7. Thickness } \\
\text { at shaft } \\
\text { end }(\mathrm{mm})\end{array}$ & $\begin{array}{l}\text { 8. Width of } \\
\text { gape (mm) }\end{array}$ \\
\hline $\begin{array}{l}\text { Hook A; rotating hook, } \\
\text { Tectus niloticus }\end{array}$ & 35.77 & 33.43 & 34.11 & 8.87 & 5.09 & 3.68 & 4.6 & 12.13 \\
\hline $\begin{array}{l}\text { Hook B; rotating hook, } \\
\text { Tectus niloticus }\end{array}$ & 28.62 & 26.85 & 27.37 & 7.57 & 3.95 & 2.14 & 3.35 & 7.9 \\
\hline $\begin{array}{l}\text { Hook C; rotating hook, } \\
\text { Tectus niloticus, } \mathrm{C}^{14} \text { dated }\end{array}$ & 33.24 & 31.86 & 32.53 & 9.49 & 4.89 & 2.9 & 3.14 & 11.78 \\
\hline $\begin{array}{l}\text { Hook D; jabbing hook, } \\
\text { Tectus niloticus }\end{array}$ & - & - & - & - & - & 2.21 & - & - \\
\hline $\begin{array}{l}\text { Hook E; rotating hook, } \\
\text { Tectus niloticus }\end{array}$ & 31.14 & 28.55 & 28.75 & 6.8 & 4.12 & 2.09 & 3.79 & 7.84 \\
\hline $\begin{array}{l}\text { Bivalve, Vasticardium cf. } \\
\text { flavum }\end{array}$ & $50.65(\max )$ & - & $44.00(\max )$ & - & - & - & - & - \\
\hline
\end{tabular}


worn around the neck and could be used to replace those lost or broken during fishing (Figure S2).

None of the Alor hooks are barbed, and none have a notched shank for securing the line (Figure 7). Rotating hooks found in prehistoric contexts elsewhere in the world, along with ethnographic accounts of hook use, show that while some hooks have knobs or notches to prevent slippage of the line, many do not (see OSM, Figures S2 (central panel) \& S3). Anell (1955) illustrates and discusses rotating hooks from throughout Oceania where the shaft has no modification to attach a line (Figure S3). Instead, the line was secured by lashing it along

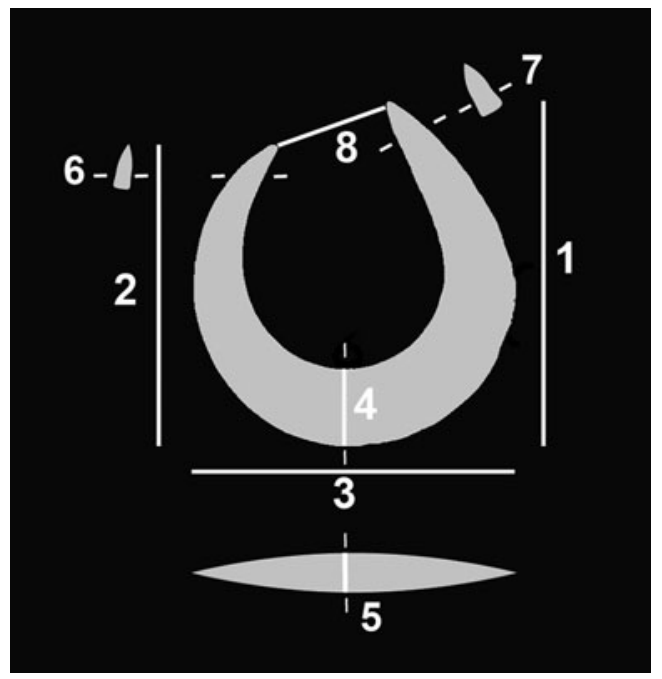

Figure 9. Schematic diagram showing the location of measurements taken on hooks in Table 2. the length of the shank, and in some instances partway around the bend. This also appears to be the case with some of the archaeological rotating hooks from Espíritu Santo, Mexico, dating to about 8500 cal BP, and from the southern California coast $(3000 \mathrm{cal} \mathrm{BP})$, which also come to a point at the end of the shank akin to the Alor hooks (Hoover 1973; Rick et al. 2002).

The Tectus niloticus shell of which the Alor hooks are made is highly lustrous when the outer periostracum layer is removed. This quality apparently enhanced hook performance (Fujita 2014), and in western Melanesia, single-piece Tectus hooks were sometimes used without bait, their lustre being sufficient to attract the fish (Anell 1955).

\section{Discussion}

Fossil remains of modern humans dating prior to the Holocene are rare east of the Wallace Line in Island Southeast Asia, and burials of this age containing grave goods have not previously been reported (Piper 2016: 33-34). Burials dating to between c. 12000 and $9000 \mathrm{cal}$ BP found in the West Mouth of Niah Cave on Sarawak indicate complex treatment of the bodies of the deceased, but grave goods have only been found with one flexed inhumation (burial 27), which had a rhinoceros radius placed as a 'pillow' (Piper 2016: 33-34). The only other examples of burials with grave goods are a flexed burial from Hang Cho Cave in northern Vietnam, dated to $c .11000 \mathrm{cal} \mathrm{BP}$ and apparently associated with plant processing and other stone tools, and an Early Holocene burial at Song Terus in Java, which contained a monkey skull (Trachypithecus auratus) (Piper 2016: 33-34). The fishhooks placed as grave goods in the Alor burial are thus unique within Mainland and Island Southeast Asia.

Circular rotating hooks are found in archaeological contexts in Australia (Attenbrow 2010), throughout Oceania (Anell 1955; Reinman 1967; Kirch 1985; Allen 1996; Burley (C) Antiquity Publications Ltd, 2017 


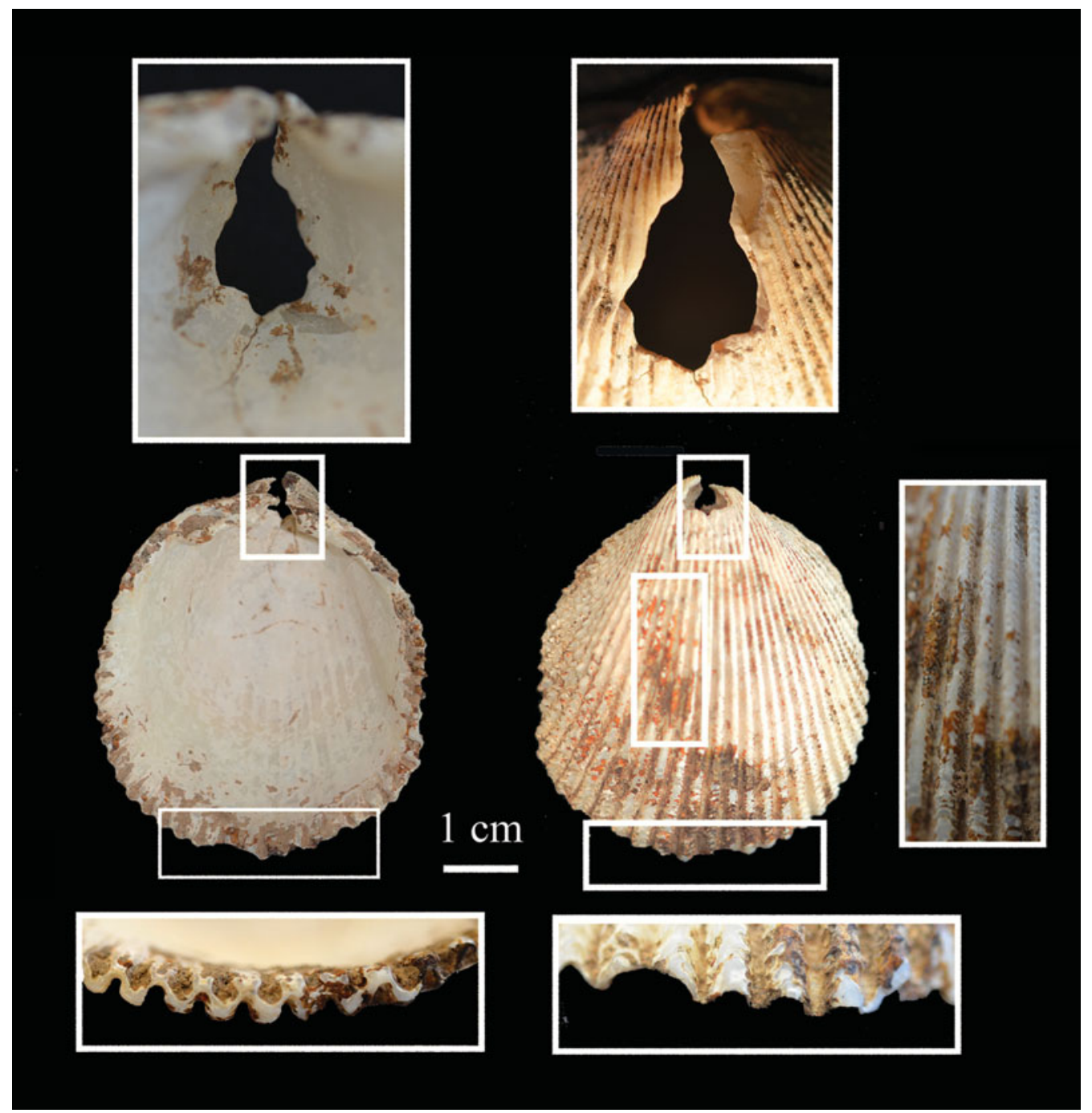

Figure 10. Bivalve Vasticardium cf. flavum (L) showing detail of the perforation at the umbo (above) and wear and rounding on the ventral margin.

\& Shutler 2007; Szabó 2007), in Japan (Fujita et al. 2016), Arabia (Santini 1987), along the California coast and islands (Rick et al. 2002), in the islands of Baja California, Mexico (Fujita 2014), Chile (Llagostera 1992) and Ecuador (Meggers \& Evans 1962; Bearéz et al. 2012) (see OSM, Figure S3). Santini (1987) comments on how similar the rotating hooks from burial RH-10 in the Qurum area of Oman are to those in the Indo-Pacific region. The rotating hook made from Tectus niloticus found on Okinawa Island dating to between c. 23000 and $20000 \mathrm{cal} \mathrm{BP}$ is also nearly identical to those in the Tron Bon Lei burial.

The technological parallels between the circular rotating hooks on the American coast and those in Polynesia have been argued to result from diffusion as a result of transpacific voyaging and culture contact (Heyerdahl 1952), migration or diffusion from Japan to

(C) Antiquity Publications Ltd, 2017 
Oceania (Anell 1955; Reinman 1967), and even inadvertent transfer by migrating tuna (Landberg 1966). The absence of such hooks in Indonesia led Heyerdahl (1952) to speculate that they had their origin on the coast of South America and then spread to Polynesia. The appearance of almost identical hooks in Japan, Indonesia and TimorLeste, dated to the Terminal Pleistocene, and their absence in the Philippines, Borneo, Sarawak and other Indonesian islands at this early date makes cultural diffusion an unlikely explanation for their appearance in the archaeological record in widely spaced regions of the world. Rather, rotating hooks can be seen as an example of convergent cultural evolution in technology, in which this particular morphology arose independently in different areas as a response to particular functional requirements and under similar ecological conditions.

\section{Conclusion}

In both life and death, the Pleistocene inhabitants of Alor Island were intrinsically connected to the sea. The association of the fish-hooks with a burial denotes the cosmological status of fishing in this island environment, probably because of the role that fishing played during daily life for the inhabitants of an island that largely lacked other sources of protein. If the burial is confirmed as that of a female, the inclusion of fish-hooks as grave goods may indicate that women were responsible for hook-and-line fishing in Alor, as they were in Australia.

The Alor hooks, which bear an uncanny resemblance to the rotating hooks used in Japan, Australia, Arabia, California, Chile, Mexico and Oceania, provide a salutary warning against reading cultural diffusion as the cause of such similarities. Convergent technological evolution, whereby the same form of artefact develops independently in multiple, widely spaced locations because it is the most fitting form to meet the functional requirements of particular ecological conditions, is clearly possible. We argue that it is the most probable explanation for the distribution of circular rotating hooks in these widely spaced locales across the globe. To our knowledge, the fish-hooks from Alor represent the earliest excavated evidence for a direct link between cosmology and fishing. These finds, in conjunction with rare representations of fish found in the late Pleistocene rock art of France and Egypt (Roussot 1984; Huyge et al. 2011), and fish-hooks in burials dated from the Early Holocene in Siberia and Oman (Santini 1987; Basaliiski 2010), speak to the cosmological significance of fishing to late Palaeolithic societies throughout the world, perhaps to a larger extent than has previously been recognised.

\section{Acknowledgements}

An ARC Laureate to O'Connor (FL120100156) funded the research, which was conducted under an Indonesian Foreign Research Permit (O'Connor 1304/FRP/SM/V/2014). We would like to thank the community of Lerabain, the students from Universitas Gadjah Mada, Yogyakarta, and Putu Yuda from Balar Arkeologi Bali.

\section{Supplementary material}

To view supplementary material for this article, please visit https://doi.org/10.15184/aqy. 2017.186

(C) Antiquity Publications Ltd, 2017 


\section{References}

Allen, M. 1996. Style and function in east Polynesian fish-hooks. Antiquity 70: 97-116. https://doi.org/10.1017/S0003598X00082922

Anell, B. 1955. Contribution to the history of fishing in the southern seas (Studia Uppsala Ethnographica Upsaliensia IX). Uppsala: Almqvist \& Wiksells Boktryckeri.

Attenbrow, V. 2010. Aboriginal fishing on Port Jackson, and the introduction of shell fish-hooks to coastal New South Wales, Australia, in P. Hutching, D. Lunney \& D. Hochuli (ed.) The natural history of Sydney: 16-34. Mosman: Royal Zoological Society of New South Wales.

BASALIISKI, V. 2010. Mesolithic and Neolithic mortuary complexes in the Baikal region, in A. Weber, A. Katzenberg \& T. Schurr (ed.) Prehistoric hunter-gatherers of the Baikal Region, Siberia: bioarchaeological studies of past lifeways: 51-86. Philadelphia: University of Pennsylvania Press.

Bearéz, P., P. Gay \& R. Lunniss. 2012. Sea fishing at Salango (Manabi Province, Ecuador) during the middle Formative Machalilla Phase. Latin American Antiquity 23: 195-214. https://doi.org/10.7183/1045-6635.23.2.195

Bowers, S. 1883. Fishhooks from southern California. Science 1: 575 . https://doi.org/10.1126/science.ns-1.20.575-a

Brock, F., T. Higham \& C. Bronk Ramsey. 2010. Pre-screening techniques for identification of samples suitable for radiocarbon dating of poorly preserved bones. Journal of Archaeological Science 37: 855-65. https://doi.org/10.1016/j.jas.2009.11.015

Brock, F., R. Wood, T. Higham, P. Ditchfield, A. Bayliss \& C. Bronk Ramsey. 2012. Reliability of nitrogen content $(\% \mathrm{~N})$ and carbon:nitrogen atomic ratios $(\mathrm{C}: \mathrm{N})$ as indicators of collagen preservation suitable for radiocarbon dating. Radiocarbon 54: 879-86. https://doi.org/10.1017/S0033822200047524

Bronk Ramsey, C. 2009. Bayesian analysis of radiocarbon dates. Radiocarbon 51: 337-60. https://doi.org/10.1017/S0033822200033865

Burley, D. \& R. Shutler. 2007. Ancestral Polynesian fishing gear: archaeological insights from Tonga, in A. Anderson, K. Green \& F. Leach (ed.) Vastly ingenious: the archaeology of Pacific material culture: in honour of Janet Davidson: 155-71. Dunedin: Otago University Press.

Des Lauriers, M. 2010. Island of Fogs: archaeological and ethnohistorical investigations of Isla Cedros, Baja California. Salt Lake City: University of Utah Press.
Fujita, H. 2014. Early Holocene pearl oyster circular fishhooks and ornaments on Espíritu Santo Island, Baja California Sur. Monographs of the Western North American Naturalist 7: 129-34. https://doi.org/10.3398/042.007.0113

Fujita, M., S. Yamasaki, C. Katagiri, I. Oshiro, K. Sano, T. Kurozumi, H. Sugawara, D. Kunikita, H. Matsuzaki, A. Kano, T. Okumura, T. Sone, H. Fujita, S. Kobayashi, T. Naruse, M. Kondo, S. Matsu'ura, G. Suwa \& Y. KAIfu. 2016. Advanced maritime adaptation in the western Pacific coastal region extends back to 35,000-30,000 years before present. Proceedings of the National Academy of Sciences of the USA 113: 11184-89. https://doi.org/10.1073/pnas. 1607857113

Gramsch, B., J. Beran, S. Hanik \& S. Sommer. 2013. A Palaeolithic fish hook made of ivory and the earliest fish hook tradition in Europe. Journal of Archaeological Science 40: 2458-63. https://doi.org/10.1016/j.jas.2013.01.010

Greenwood, R. 1978. Obispeño and Purisimeño Chumash, in R. Heizer (ed.) Handbook of North American Indians: 520-23. Washington, D.C.: Smithsonian Institution.

Hawkins, S., S.C. Samper Carro, J. Louys, S. O'Connor \& MahirTa. 2017. Human palaeoecological interactions and owl roosting at Tron Bon Lei, Alor Island, eastern Indonesia. Journal of Island and Coastal Archaeology. First published online 1 March 2017. https://doi.org/10.1080/15564894.2017.1285834.

Heyerdahl, T. 1952. American Indians in the Pacific. London: George Allen \& Unwin.

Hoover, R. 1973. Chumash fishing equipment (Ethnic Technology Notes 9). San Diego (CA): San Diego Museum of Man.

Huyge, D., D.A.G. Vandenberghe, M. De Dapper, F. Mees, W. Claes \& J.C. Darnell. 2011. First evidence of Pleistocene rock art in North Africa: securing the age of the Qurta petroglyphs (Egypt) through OSL dating. Antiquity 85: 1184-93. https://doi.org/10.1017/S0003598X00061998

JoHANnEs, R. 1981. Words of the lagoon: fishing and marine lore in the Palau District of Micronesia. Oakland: University of California Press.

KIRCH, P. 1985. Feathered gods and fishhooks: an introduction to Hawaiian archaeology and prehistory. Honolulu: University of Hawai'i Press.

LANDBERg, L. 1966. Tuna tagging and the extra-Oceanic distribution of curved, single-piece shell fishhooks in the Pacific. American Antiquity 31: 485-93. https://doi.org/10.2307/2694380 
Llagostera, A. 1992. Early occupations and the emergence of fishermen on the Pacific Coast of South America. Andean Past 3: 87-109.

Meggers, B. \& C. Evans. 1962. The Machalilla Culture: an early formative complex on the Ecuadorian coast. American Antiquity 28: 186-92. https://doi.org/10.2307/278376

Meindl, R., C. Lovejoy, R. Mensforth \& L. Carlos. 1985. Accuracy and direction of error in the sexing of the skeleton: implications for paleodemography. American Journal of Physical Anthropology 68: 78-85. https://doi.org/10.1002/ajpa.1330680108

Nordhoff, C. 1930. Notes on the off-shore fishing of the Society Islands. Journal of the Polynesian Society 39: 137-73.

O’Connor, S., R. Ono \& C. Clarkson. 2011. Pelagic fishing at 42,000 years before the present and maritime skills of modern humans. Science 334: 1117-21. https://doi.org/10.1126/science. 1207703

Piper, P.J. 2016. Human cultural, technological and adaptive changes from the end of the Pleistocene to the mid-Holocene in Southeast Asia, in M. Oxenham \& H.R. Buckley (ed.) The Routledge handbook of bioarchaeology in Southeast Asia and the Pacific: 24-45. New York: Taylor \& Francis.

Reimer, P., E. Bard, A. Bayliss, J. Beck, P. Blackwell, C. Bronk Ramsey, C. Buck, H. Cheng, R. Edwards, M. Friedrich, P. Grootes, T. Guilderson, H. Haflidason, I. Hajdas, C. Hatté, T. Heaton, T. Hoffman, A. Hogg, K. Hughen, K. Kaiser, B. Kromer, S. Manning, M. Niu, R. Reimer, D. Richards, E. Scott, J. Southon, R. Staff, C. Turney $\&$ J. van Der Plicht. 2013. IntCal13 and Marine13 radiocarbon age calibration curves $0-50,000$ years cal BP. Radiocarbon 55: 1869-87.

https://doi.org/10.2458/azu_js_rc.55.16947
Reinman, F. 1967. Fishing: an aspect of Oceanic economy: an archaeological approach. Fieldiana Anthropology 56: 95-208.

Rick, T., R. Vellanoweth, J. Erlandson \& D. Kennett. 2002. On the antiquity of the single-piece shell fishhook: AMS radiocarbon evidence from the southern California coast. Journal of Archaeological Science 29: 933-42. https://doi.org/10.1006/jasc.2001.0788

Roussot, A. 1984. Peintures, gravures et sculptures de l'abri du poisson aux Eyzies: quelques nouvelles observations. Préhistoire Ariégeoise. Bulletin de la Société Préhistorique de l'Ariège-Pyrénées 39: 11-26.

Samper Carro, S.C., S. O’Connor, J. Louys, S. Hawkins \& M. Mahirta. 2016. Human maritime subsistence strategies in the Lesser Sunda Islands during the Terminal Pleistocene-Early Holocene: new evidence from Alor, Indonesia. Quaternary International 416: 64-79. https://doi.org/10.1016/j.quaint.2015.07.068

SANTINI, G. 1987. Site RH-10 at Qurum and a preliminary analysis of its cemetery: an essay in stratigraphic discontinuity. Proceedings of the Seminar for Arabian Studies 17: 179-98.

Szabó, K. 2007. An assessment of shell fishhooks of the Lapita cultural complex, in A. Anderson, K. Green \& F. Leach (ed.) Vastly ingenious: the archaeology of Pacific material culture: in honour of Janet Davidson: 227-41. Dunedin: Otago University Press.

Received: 12 December 2016; Accepted: 13 March 2017; Revised: 28 March 2017

(C) Antiquity Publications Ltd, 2017 